\title{
GENETIC DIVERSITY IN ALGERIAN DURUM WHEAT VARIETIES (Triticum turgidum L var. durum) USING MICROSATELLITE MARKERS
}

\author{
DIVERSIDADE GENÉTICA EM VARIEDADES DE TRIGO DURO ARGELINO \\ (Triticum turgidum L var. durum) USANDO MARCADORES MICROSSATÉLITES
}

\author{
Abderrezzak KIROUANI ${ }^{1}$; Fatima HENKRAR ${ }^{2}$; Sripada M UDUPA ${ }^{3}$; \\ Leila BOUKHALFOUN ${ }^{4}$; Hamenna BOUZERZOUR ${ }^{5}$ \\ 1. Scholar Phd at Saad Dahleb University of Blida, Algeria. 2. Phd at ICARDA-Rabat, Morocco ; 3. Phd, Biotechnologist/Geneticist at \\ ICARDA-Rabat, Morocco; 4. Scholar Phd at M'Hamed Bougara of Boumerdes, Algeria. 5. PES at Farhat Abbas University of Setif, \\ Algeria.
}

\begin{abstract}
Characterization of germplasm by DNA-markers provides powerful tool to precise germplasm identification. This study aimed to quantify the genetic diversity and to estimate the phylogenetic relationship among genotypes in many crop species. The results of the present study realized between Nov and Dec 2016 in biotechnologie unit (ICARDA, Morocco) which aimed to characterize a subset of 14 Algerian selected durum wheat cultivars (Triticum turgidum L. var. durum), using 13 SSR (Single Sequence Repeat) indicated the presence of a total of 39 alleles. The genetic diversity at the 13 microsatellites loci varied from 0,142 for $X g w m 337$ to 0.735 for Xgwm213 with a mean of 0.444. Polymorphic information content (PIC) values ranged from 0.13 to 0.70 and the genetic distance among the cultivars from 0.15 to 0.77 . Clustering analysis showed that the studied varieties were grouped according to their population of origin, suggesting a provenance effect in their ordination. In fact the most similar varieties were those introduced from CIMMYT-ICARDA breeding program, which may have common parents in their pedigree. Selections from local landraces were more similar to each other and dissimilar to CIMMYT-ICARDA material, showing an agroecological adaptation.
\end{abstract}

KEYWORDS: Durum wheat: SSR markers: Characterization: Relationship.

\section{INTRODUCTION}

Durum wheat (Triticum turgidum $\mathrm{L}$ var. durum) is cultivated on $10 \%$ of the world wheat areas. The total area and production are about 15 million hectares and 31 million metric tons, respectively (http://www.fas.usda.gov)_.It is mainly grown in South European, North African and West Asian countries (MACCAFERRI et al., 2003). Algeria produces 2 million tons of durum wheat and imports almost the same quantity (1.7 million tons, 2011-2015 average) to meet a growing domestic demand (RUSH, 2016). Durum wheat is cultivated mainly on the high plateaus characterized by altitude, cold winters, low rainfall and high temperatures at the end of crop cycle, which affect seriously grain yield (MEKHELOUF et al., 2006). Further expansion of the cultivated area is not possible, and increase productivity remains as an interesting alternative to reduce the gap between production and consumption. Development of improved varieties with high yielding potential and adapted to variable environments is intended through classical breeding. To face the increasing demand for wheat, it will be important to breed new varieties of durum wheat that can withstand biotic and abiotic stresses while maintaining yields and quality. Unlike the traditional process of phenotypic selection, which is too expensive and laborintensive, new genetic and genomic approaches have been adopted to improve germplasm characterization at the molecular level. Very little, if any, efforts have been given to molecular investigation. Fingerprinting and genetic relationships among durum wheat varieties and lines released for production in Algeria have not been done to date. Very few research references are available on the genetic information of this crop species. Genetic diversity analysis of durum wheat has been reported by Yousfi (2009), who studied fourteen durum and bread wheat cultivars to explore the polymorphism of several SSR markers located on chromosome 7A, which was associated with drought tolerance. This author found that most Algerian cultivars showed a polymorphism quite different from that found in Romanian cultivars. Genetic diversity studies are needed for proper choice of parents to generate crosses with broad genetic base. Genetic diversity is defined as the amount of genetic variability which is reflected in differences of DNA sequences among individuals (RAO; HODGKIN, 2002). Knowledge of germplasm diversity and genetic relationships among breeding materials are valuable aids in crop improvement. Fufa et al. (2005) mentioned that knowledge of genetic diversity of elite breeding 
materials has been successfully used for efficient germplasm management, genotype selection for different plant breeding purposes, and the conservation of genetic resources. Molecular markers play a pivotal role in varietal evaluation; they can speed up the process and decrease the amount of plant material that needs to be screened (ASTARINI et al., 2004). Microsatellites have been used for analysis of genetic diversity and identification of varieties (Al KHANJARI et al., 2007; Tautz et al., 1986). Their simplicity, high level of polymorphism, high reproducibility makes them popular for evolutionary and genetic diversity studies (WANG et al., 2007). The objective of this study was to determine the genetic diversity existing among 14 durum wheat varieties, and to ascertain their genetic structure.

\section{MATERIAL AND METHODS}

\section{Plant materials, DNA extraction and microsatellites amplification}

Fourteen durum wheat varieties (Table 1), obtained from the Algerian Field Crops Institute, Agricultural Research Station of OuedSmar (ITGC, ARS, OuedSmar, Algeria) were used as plant material. Seedlings were grown in the greenhouse of Biotechnology Unit, INRA/ICARDA-Morocco. Fresh leaves of 10 seedlings, 2 week-old, were harvested in bulk, lyophilized and used for DNA extraction (Table 1).

Table 1. Name, pedigree and cross origin of the fourteen durum wheat genotypes studied

\begin{tabular}{ccc}
\hline Name & Pedigree & Cross origin \\
\hline Bidi $_{17}$ & Landrace selection & INRA Algeria \\
Chen's & Ichwa'S'/Bit 'S'CD 26406 & CIMMYT-ICARDA \\
Gta dur & Crane/4/PolonicumPI ${ }_{18530} / /$ T.glutin en/2* Tc60/3/Gll & CIMMYT-ICARDA \\
Hedba 03 & Landrace selection & INRA Algeria \\
MBB & Landrace selection & INRA Algeria \\
Simeto & Capeiti8/Valvona & Italy \\
Mexicali & GdoVz 469/3/Jo'S”/61.130.Lds/Stk”S”CM470 & CIMMYT \\
Vitron & Turkey77/3/Jori/Anhinga//Flamingo & CIMMYT \\
Waha & Plc/Ruff//Gta's/3/Rolette CM 17904 & CIMMYT \\
Cirta & KB214-0KB-20KB-OKB-OKB-1KB-0KB & ITGC, ARS, Khroub, Algeria \\
Ofanto & Appulo/Adamello & Italy \\
Bousselam & Heider/Martes/Huevos de Oro. ICD-414 & CIMMYT-ICARDA \\
Megress & Ofanto/Waha//MBB & ITGC, ARS, Setif, Algeria \\
Amar6 & ID94.0920-C-OAP.7AP & CIMMYT-ICARDA \\
\hline
\end{tabular}

Genomic DNA was extracted using the CTAB method (Saghai-Maroof et al., 1984) with minor modifications, using $2 \%$ CTAB buffer for extraction instead of $1 \% \mathrm{CTAB}$ and using sterile distilled water for dissolution of the final DNA pellet instead of $10 \mathrm{mM} \mathrm{NH} \mathrm{NH}_{4} \mathrm{OAc} / 0.25 \mathrm{mM}$ EDTA (ethylene diamine tetra acetic acid), as described by (UDUPA et al., 1999). Quality and quantity of the isolated DNA were assessed by intactness and intensity of the DNA band, respectively, obtained after electrophoresis of $3 \mu \mathrm{L}$ of the isolated DNA in $1 \%$ agarose $(\mathrm{w} / \mathrm{v})$ gel, stained with ethidium bromide and visualized under Ultra Violet (U.V.) rays. The intensity of the band of isolated DNA was compared to known concentrations of lambda DNA digested with EcoRI and HindIII restriction enzymes.

\section{Microsatellites amplification}

Fourteen durum wheat varieties were screened with 13 genomic SSR primers (Table 2). Polymerase Chain Reactions (PCR) was performed in a volume of $10 \mu \mathrm{L}$, containing $1 \mathrm{x}$ PCR buffer $\left(1.5 \mathrm{mM} \mathrm{MgCl} \mathrm{Mg}_{2}\right), 200 \mu \mathrm{M}$ of each dNTPs, 10 Pico moles of each primer, $0.5 \mathrm{U}$ of Taq DNA polymerase and approximately $50 \mathrm{ng}$ of genomic DNA. The amplification reaction was generated in the Eppendorf Master cycler with initial denaturation for five minutes at $94^{\circ} \mathrm{C}$, followed by 35 cycles of each cycle with 30 seconds denaturation at $94^{\circ} \mathrm{C}, 30$ seconds annealing at $59^{\circ} \mathrm{C}, 45$ seconds extension at $72^{\circ} \mathrm{C}$. Final extension was carried out at $2^{\circ} \mathrm{C}$ for five minutes followed by cooling at $4^{\circ} \mathrm{C}$.

Amplified products were separated on $6 \%$ $(\mathrm{w} / \mathrm{v})$ denaturing polyacrylamide gels. The amplified bands were detected by silver staining. The size of each band was estimated by means of a 100-bp DNA 
marker ladder. DNA fragments were scored for presence and absence for the studied cultivars. Effective allele per locus (Aep) were calculated according to (HUDSON, 1990) with the formula $1 /(1-\mathrm{Hep})$, where Hep is the genetic diversity per locus. The polymorphic information content (PIC) were calculated using formula $1-\Sigma \mathrm{Pi}^{2}$ with $\mathrm{Pi}$ is equal to the frequency of the $\mathrm{i}^{\text {th }}$ allele at the locus (ANDERSON et al., 1993).

Table 2. Marker, linkage group, primer forward and reverse sequences of 13 microsatellite markers used in this study

\begin{tabular}{|c|c|c|}
\hline Marker & Linkage group & Forward and Reverse primer sequence \\
\hline \multirow[t]{2}{*}{ Xbarc263 } & $1 \mathrm{~A}$ & F- 5' GGAAGCGCGTCAGCACTAGGCAAC 3' \\
\hline & & R- 5' GGCTTCTAGGTGCTGCGGCTTTTGTC 3' \\
\hline \multirow[t]{2}{*}{ Xgwm106 } & $1 \mathrm{~A}$ & F- 5' CTGTTCTTGCGTGGCATTAA 3' \\
\hline & & R- 5' AATAAGGACACAATTGGGATGG 3' \\
\hline \multirow[t]{2}{*}{ Xgwm369 } & $3 \mathrm{~A}$ & F- 5' CTGTTCTTGCGTGGCATTAA 3' \\
\hline & & R- 5' AATAAGGACACAATTGGGATGG 3' \\
\hline \multirow[t]{2}{*}{ Xgwm397 } & $4 \mathrm{~A}$ & F- 5' CTGCAGGCCATGATGATG 3' \\
\hline & & R- 5' ACCGTGGGTGTTGTGAGC 3' \\
\hline \multirow[t]{2}{*}{ Xgwm337 } & 1B & F- 5' ССТСТТССТСССТСАСТTAGC 3' \\
\hline & & R- 5' TGCTAACTGGCCTTTGCC 3' \\
\hline \multirow[t]{2}{*}{ Xwmc477 } & $2 \mathrm{~B}$ & F- 5' CGT CGAAAACCGTACACTCTCC 3' \\
\hline & & R- 5' GCG AAA CAG AAT AGC CCT GAT G 3' \\
\hline \multirow[t]{2}{*}{ Xbarc101 } & $2 \mathrm{~B}$ & F- 5' GCTCCTCTCACGATCACGCAAAG 3' \\
\hline & & R- 5' GCGAGTCGATCACACTATGAGCCAATG 3' \\
\hline \multirow[t]{2}{*}{ Xgwm493 } & 3B & F- 5' TTCCCATAACTAAAACCGCG 3' \\
\hline & & R- 5' GGAACATCATTTCTGGACTTTG 3' \\
\hline \multirow[t]{2}{*}{ Xgwm 213} & $5 \mathrm{~B}$ & F- 5' TGCCTGGCTCGTTCTATCTC 3' \\
\hline & & R- 5' CTAGCTTAGCACTGTCGCCC 3' \\
\hline \multirow[t]{2}{*}{ Xgwm193 } & $6 \mathrm{~B}$ & F- 5' CTTTGTGCACCTCTCTCTCC 3' \\
\hline & & R- 5' AATTGTGTTGATGATTTGGGG 3' \\
\hline \multirow[t]{2}{*}{ Xgwm644 } & $6 \mathrm{~B}$ & F- 5' GTGGGTCAAGGCCAAGG3' \\
\hline & & R- 5' AGGAGTAGCGTGAGGGGC 3' \\
\hline \multirow[t]{2}{*}{ Xgwm111 } & 7B & F- 5' TCTGTAGGCTCTCTCCGACTG 3' \\
\hline & & R- 5' ACCTGATCAGATCCCACTCG 3' \\
\hline \multirow[t]{2}{*}{ Xgwm577 } & 7B & F- 5' ATGGCATAATTTGGTGAAATTG 3' \\
\hline & & R- 5' TGTTTCAAGCCCAACTTCTATT 3' \\
\hline
\end{tabular}

\section{Data analysis}

Power Marker software, Ver. 3.0 (LIU; MUSE, 2005), was used to calculate genetic diversity, number of alleles and the shared allele genetic distance (Jin and Chakraborty, 1994). A dendrogram was constructed based on genetic distance by using the Neighbor-joining (NJ) method (SAITOU; NEI, 1987) and visualized using MEGA5 software (TAMURA et al., 2011). Principal Coordinates Analysis (PCoA) was undertaken using GenAlEx 6.5 software (PEAKALL; SMOUSE, 2012).

\section{RESULTS AND DISCUSSION}

\section{Microsatellite polymorphism}

A total of 39 alleles were detected, the number of alleles per locus was ranged from 2 for
Xgwm106, Xgwm369, Xgwm337, Xgwm493 and $X g w m 111$ to 6 for Xgwm213, the average number of alleles was 3.00 (Table 3).

The genetic diversity (Hep) was varied from 0,142 for $X g w m 337$ to 0.735 for Xgwm213 with an average of 0.444 (Table 3). Maccaferri et al. (2003) reported that SSR markers detected an average of 5.6 different allelic variants per locus, with a mean diversity equal to 0.560 , comparatively the figures reported in the present study are somewhat lower (Table 3). Bantte and Mogus (2016) reported genetic dissimilarity among sorghum lines ranging from 0.326 to 0.839 with an average of 0.672 . Yildirim et al. (2011) studied durum wheat genetic diversity, found that polymorphic bands ranged from 4 to 9 per SSR locus and the most polymorphic SSR loci were Wms18, Wms155, Xgwm166 and Stm578. Gorji and Zolnoori (2011) reported that the number of alleles observed per locus ranged from two to five with an average of 3.26 , among 23 
polymorphic loci. The same authors observed that the genetic diversity per locus or polymorphic information content, which estimated the informativeness at each locus, varied from 0.19 to 0.78 with a mean of 0.49 .

Table 3. Number of alleles, genetic diversity and polymorphic information content in fourteen durum wheat genotypes using 13 markers

\begin{tabular}{cccc}
\hline Markers & Alleles Number & Genetic diversity $(\mathbf{H})$ & PIC \\
\hline Xbarc263 & 3 & 0.379 & 0.34 \\
\hline Xgwm106 & 2 & 0.337 & 0.28 \\
Xgwm369 & 2 & 0.245 & 0.21 \\
Xgwm397 & 4 & 0.704 & 0.65 \\
Xgwm337 & 2 & 0.142 & 0.13 \\
Xwmc477 & 3 & 0.255 & 0.24 \\
Xbarc101 & 3 & 0.500 & 0.43 \\
Xgwm493 & 2 & 0.497 & 0.37 \\
Xgwm213 & 6 & 0.735 & 0.70 \\
Xgwm193 & 3 & 0.622 & 0.55 \\
Xgwm644 & 3 & 0.255 & 0.24 \\
Xgwm111 & 2 & 0.490 & 0.37 \\
Xgwm577 & 4 & 0.612 & 0.54 \\
Total & 39 & - & - \\
Mean & 3 & 0.440 & 0.39 \\
Stand Dev & 1.15 & 0.190 & \\
\hline
\end{tabular}

According to Botstein et al. (1980), a marker is highly informative if its PIC is greater than 0.500 . In the present study markers which were the most informative were Xgwm213, Xgwm397, Xgwm193 and Xgwm577 with PIC values of 0.70, $0.65,0.55$, and 0.54 , respectively. The PIC has been used in several studies to assess the discriminatory power of the primer for cultivar identification (TATIKONDA et al., 2009). Mangini et al. (2010) reported a mean value of the polymorphic information content of 0.75 for 11 microsatellite markers, with a range of 0.42 to 0.96 . One marker, the Xwmc597, showed the highest polymorphic information content, and was able to distinguish all the 28 durum wheat studied cultivars. The high informativeness of some markers could be explained by their multi-locus nature. In fact Somers et al. (2004) found that some SSR markers showed loci on two or more chromosomes. Mangini et al. (2010) found that Xwmc597 marker mapped on 1B, 2B, 3B, $4 \mathrm{~B}$ and $6 \mathrm{~B}$ chromosomes and that Xwmc415 was localized on $5 \mathrm{~A}$ and $5 \mathrm{~B}$ chromosomes. This explains the relative superiority of SSR loci for detecting DNA polymorphism.

\section{Genetic relationships among varieties}

A dendrogram was constructed based on the shared allele genetic distance. all the 14 durum wheat genotypes were easily discriminated and clustered into 3 major groups (Figure 1). The first group assembled Megress, Hedba ${ }_{03}$, Bidi17, Ofanto and Mohamed Ben Bachir. The second group constituted of Mexicali, simeto, Gta Dur and Waha, and last group assembled Chen's, Cirta, Amar6, Boussallem and Vitron 


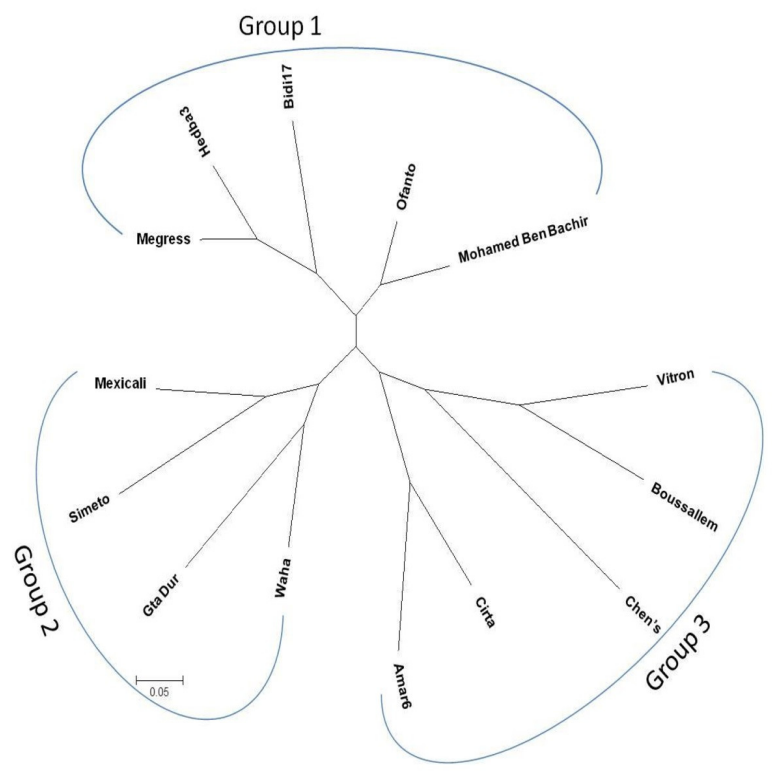

Figure 1. Dendogram of 14 durum wheat genotypes based on microsatellite data using shared allele genetic distance and Neighbor-joining method

The highest genetic distance was observed between Simeto and Vitron, (0.77), and between Bousselam and Cirta (0.73). The smallest genetic distance was observed between Megress and $\operatorname{Hedba}_{03}(0.15)$ and between Ofanto and MBB $(0.15$, Figure 1). Genotype clustering seems to be based on the pedigree relationship or similarity of the breeding materials source. In fact, the most similar varieties were those introduced from CIMMYTICARDA breeding program, which may have common parents in their pedigree. Selections from local landraces were more similar to each other and dissimilar to CIMMYT-ICARDA material. This difference may be due to specific agro-ecological adaptation of the latter cited group of varieties. Maccaferri et al. (2003) noted that a large portion of the molecular variation detected within 45 modern cultivars was accounted for by SSR alleles tracing back to ten foundation-genotypes; among which CIMMYT-derived founders were genetically distant from the old Mediterranean varieties. Yildirim et al. (2011) reported that durum wheat varieties were clustered into two major groups, from which the genetically closest and farthest genotypes were identified. The results of the present study indicated that there is ample genetic diversity among the studied genotypes. This diversity could be useful for planning more promising crosses, assigning varieties to specific heterotic groups, and exploit expressive genetic variability by using only adapted germplasm. These results corroborate those of Plaschke et al. (1995) who reported that few markers were sufficient in detecting polymorphism among wheat genotypes.

Principal-coordinate analysis ( $\mathrm{PCoA})$ was chosen to complete the information coming out from cluster analysis. According to Quinn and Keough (2002), cluster analysis is more sensitive to closely related individuals while PCoA is more informative regarding distances among major groups. PCoA revealed that the first two axes, presented eigenvalues greater than unity (2.02 and 1.27 respectively) and explained $57.66 \%$ of the total variation (35.69 and $22.26 \%$, respectively). In the two-dimensional space, the studied varieties were clearly separated along the first two PCoA coordinates. Five groups can be identified in the diagram highlighted by encircling genotypes belonging to each of the five main groups (Figure 2). 


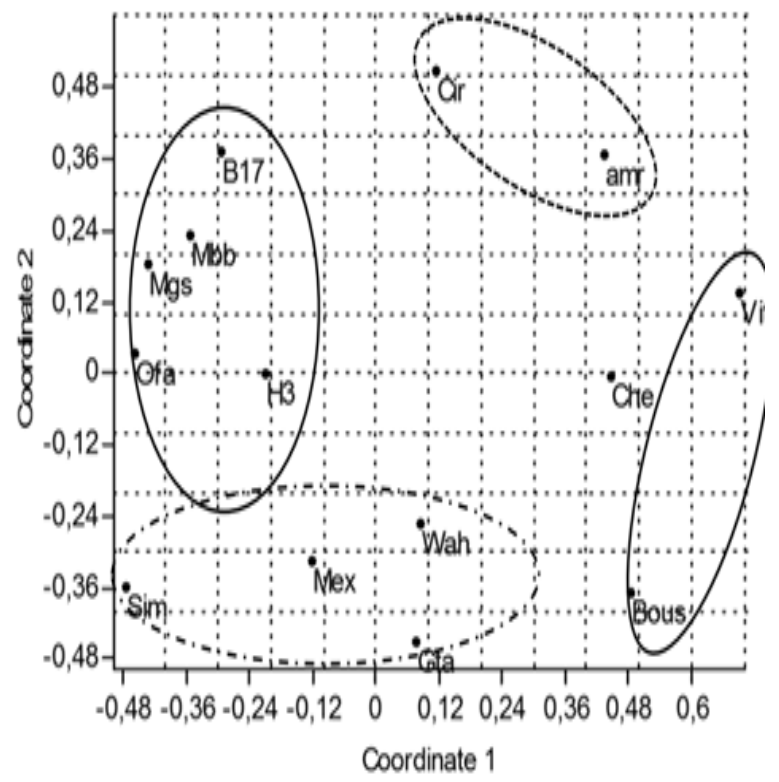

Figure 2. Scatter plot of the first and second principal coordinates, after an analysis of genetic diversity derived from 13 microsatellite loci in 14 Algerian durum wheat varieties $\left(A m r=\right.$ Ammar $_{6}, \quad B 17=$ Bidi $_{17}$, Bous $=$ Bousselam, Che $=$ Chen's, Cir $=$ Cirta, Gta $=$ Gaviota durum, H3 $=$ Hedba $_{03}, \mathrm{Mbb}=$ Mohamed Ben Bachir, Mex= Mexicali, Mgs=Megress, Ofa= Ofanto, Sim= Simeto, Vit= Vitron, Wah= Waha)

The studied varieties are grouped according to their population of origin, indicating a provenance effect in their ordination. Along the first PCoA coordinate were opposed Vitron and Bousselam (Group1) to Bidi ${ }_{17}, \mathrm{Hedba}_{03}$, Mohamed Ben Bachir, Ofanto, and Megress (Group 2). While along the second PCoA coordinate were opposed Cirta, and Ammar 6 to Gaviota durum, Mexicali, Simeto, and Waha. Chen's cultivar (group 5) was best represented on the third PCoA coordinate (data not shown) which accounted for a further $15.86 \%$ of the variation, bringing the total explained variation up to $73.81 \%$ (Figure 2). PCoA analysis indicated that land race selections form a distinct group apart from modern varieties which supports cluster analysis results. Such differentiation was observed by Maccaferri et al. (2003). The results suggested that durum wheat landraces are quite unique since they markedly differ from modern durum wheat germplasm whose variation could be traced back to differences in founders used in crosses in the CIMMYT-materials. Landrace selections are not usually integrated in the crossing program because of their tall stature, lateness and susceptibility to diseases. Molecular breeding techniques may help in pyramiding of desirable alleles from both genetic sources in the future improved varieties.

\section{CONCLUSION}

Genetic diversity using 13 microsatellite loci has been successfully employed in the molecular characterization of 14 durum wheat grown in Algeria. Genetic variation was similar to that described in other publications. These results are important for Algerian durum wheat breeding as the success of a breeding program depends largely on the availability of a wide genetic base. The selected set of SSRs has generated high polymorphism, showing its utility in the characterization of durum wheat germplasm. Landraces selections should be a good source of genetic diversity since they had a high polymorphism and they were distinguished from the CIMMYT-derived materials. This benefits durum wheat breeding programs to make best choice of varieties to be used in crosses which facilitates germplasm management.

\section{ACKNOWLEDGEMENTS}

The first author is grateful to the International Treaty for Plant Genetic Resources for Food and Agriculture/FAO, the European Union, the CRP-Wheat and ICARDA/Morocco Collaborative Grants Program for their financial support. 
RESUMO: A caracterização de germoplasma por marcadores de DNA fornece uma ferramenta poderosa para a identificação precisa de germoplasma, quantificar a diversidade genética e estimar a relação filogenética entre genótipos em muitas espécies de culturas. Os resultados do presente estudo foram realizados entre novembro e dezembro de 2016 na unidade de biotecnologia (ICARDA, Marrocos) que objetivou caracterizar um subconjunto de 14 cultivares de trigo duro argelinos selecionados (Triticum turgidum L. var. durum), utilizando 13 SSR (Single Sequence Repeat ) indicou a presença de um total de 39 alelos. A diversidade genética nos 13 locos de microssatélites variou de 0,142 para Xgwm337 a 0,735 para Xgwm213 com uma média de 0,444. Os valores do conteúdo de informação polimórfica (PIC) variaram de 0,13 a 0,70 e a distância genética entre as cultivares de 0,15 a 0,77. A análise de agrupamento mostrou que as variedades estudadas foram agrupadas de acordo com sua população de origem, sugerindo um efeito de proveniência em sua ordenação. De fato, as variedades mais similares foram aquelas introduzidas no programa de criação CIMMYT-ICARDA, que podem ter pais comuns em seu pedigree. Seleções de variedades locais foram mais similares entre si e diferentes do material CIMMYT-ICARDA, mostrando uma adaptação agroecológica.

PALAVRAS-CHAVE: Trigo duro. Marcadores SSR: Caracterização. Relacionamento.

\section{REFERENCES}

ANDERSON, J. A.; CHURCHILL, G. A.; AUTRIQUE, J. E.; TANKSLEY, S. D.; SORRELLS, M. E. Optimizing parental selection for genetic linkage maps. Genome, v. 36, n. 1, p. 181-186, 1993.

ASTARINI, I. A.; PLUMMER, J. A.; LANCASTER, R. A.; YAN, G. Fingerprinting of cauliflower cultivars using RAPD markers. Australian Journal of Agricultural Research, v. 55, p. 117-124, 2004.

BANTTE, K.; MOGUS, Y. DNA Fingerprinting and Genetic Relationship among Ethiopian Sorghum [ Sorghum bicolor ( L .) Moench ] Lines. International Journal of Plant Breeding and Genetics, v. 10, n. 1, p. 38-44, 2016.

BOTSTEIN, D.; WHITE, R. L.; SKOLNICK, M.; DAVIS, R. W. Construction of a Genetic Linkage Map in Man Using Restriction Fragment Length Polymorphisms. The American Journal of Human Genetics, v. 32, p. 314-331, 1980.

FUFA, H.; BAENZIGER, P. S.; BEECHER, B. S.; DWEIKAT, I.; GRAYBOSCH, R. A.; ESKRIDGE, K. M. Comparison of phenotypic and molecular marker-based classifications of hard red winter wheat cultivars.

Euphytica, v. 145, p. 133-146, 2005.

GORJ, A. H.; ZOLNOORI, M. Genetic diversity in héxaploïde wheat genotypes using microsatellite markers. Asian Journal of Biotechnology, v. 3, n. 4, p. 368-377, 2011.

HUDSON, R. R. Genetic Data Analysis. Methods for Discrete Population Genetic Data. Bruce S. Weir. Sinauer, Sunderland. Science, v. 250, n. 4980, p. 575-575, 1990.

JIN, L.; CHAKRABORTY, R. Estimation of Genetic Distance and Coefficient of Gene Diversity from SingleProbe Multilocus DNA Fingerprinting Data. Molecular Biology and Evolution, v. 11, n. 1, p. 120-127, 1994.

KHANJARI, S. AL; HAMMER, K.; BUERKERT, A.; RÖDER, M. S. Molecular diversity of Omani wheat revealed by microsatellites: II. Hexaploid landraces. Genetic Resources and Crop Evolution, v. 54, n. 7, p. 1407-1417, 2007.

LIU, K.; MUSE, S. V. PowerMarker : an integrated analysis environment for genetic marker analysis.

Bioinformatics, v. 21, n. 9, p. 2128-2129, 2005.

MACCAFERRI, M.; SANGUINETI, M. C.; DONINI, P.; TUBEROSA, R. Microsatellite analysis reveals a progressive widening of the genetic basis in the elite durum wheat germplasm. Theoretical and Applied

Genetics, v. 107, p. 783-797, 2003. 
MANGINI, G.; TARANTO, F.; GIOVE, S. L.; GADALETA, A.; BLANCO, A. Identification of durum wheat cultivars by a minimum number of microsatellite markers. Cereal Research Communications, v. 38, $\mathrm{n}$. 2, p. 155-162, 2010.

MEKHELOUF, A.; DEHBI, F.; BOUZERZOUR, H.; HANNCHI, A.; BENMAHAMMED, A.; ADJABI, A. Between cold tolerance, grain yield performances and stability of durum wheat (Triticum durum Desf.) genotypes grown at high elevation area of Eastern Algeria.

Asian Journal of Plant Sciences, v. 5, n. 4, p. 700-708, 2006.

PEAKALL, R.; SMOUSE, P. E. GenAlEx 6.5 : genetic analysis in Excel . Population genetic software for teaching and research — an update. Bioinformatics, v. 28, n. 19, p. 2537-2539, 2012.

PLASCHKE, J.; GANAL, M. W.; RÖDER, M. S. Detection of genetic diversity in closely related bread wheat using microsatellite markers. Theoretical and Applied Genetics, v. 91, n. 6-7, p. 1001-1007, 1995.

QUINN, G. P.; J.KEOUGH, M. Experimental Design and Data Analysis for Biologists Anessential. Cambridge University Press, New York, 2002.

RAO, V. R.; HODGKIN, T. Genetic diversity and conservation and utilization of plant genetic resources. Plant Cell, Tissue and Organ Culture, v. 68, p. 1-19, 2002.

RUSH, C. Algeria exporter guide. Global Agricultural Information Network, USDA-Foreign Agricultural service, v. AG1610, p. 14, 2016. HTTP://WWW.FAS.USDA.GOV. Home I USDA Foreign Agricultural Service.

SAGHAI-MAROOF, M. A.; SOLIMAN, K. M.; JORGENSEN, R. A.; ALLARD, R. W. Ribosomal DNA spacer-length polymorphisms in barley: Mendelian inheritance, chromosomal location, and population dynamics. Proceedings of the National Academy of Sciences. USA, v. 81, n. 24, p. 8014-8018, 1984.

SAITOU, N.; NEI, M. The Neighbor-joining Method: A New Method for Reconstructing Phylogenetic Trees. Molecular Biology and Evolution, v. 4, n. 4, p. 406-425, 1987.

SOMERS, D. J.; ISAAC, P.; EDWARDS, K. A high-density microsatellite consensus map for bread wheat ( Triticum aestivum L .). Theoretical and Applied Genetics, v. 109, p. 1105-1114, 2004.

TAMURA, K.; PETERSON, D.; PETERSON, N.; STECHER, G.; NEI, M.; KUMAR, S. MEGA5 : Molecular Evolutionary Genetics Analysis Using Maximum Likelihood, Evolutionary Distance, and Maximum Parsimony Methods. Molecular Biology and Evolution, v. 28, n. 10, p. 2731-2739, 2011.

TATIKONDA, L.; WANI, S. P.; KANNAN, S.; BEERELLI, N.; SREEDEVI, T. K.; HOISINGTON, D. A.; DEVI, P.; VARSHNEY, R. K. AFLP-based molecular characterization of an elite germplasm collection of Jatropha curcas L ., a biofuel plant. Plant Science, v. 176, p. 505-513, 2009.

TAUTZ, D.; TRICK, M.; DOVER, G. A. Cryptic simplicity in DNA is a major source of genetic variation. Nature, v. 322, p. 652-656, 1986.

UDUPA, S. M.; ROBERTSON, L. D.; WEIGAND, F.; BAUM, M.; KAHL, G. Allelic variation at ( TAA ) n microsatellite loci in a world collection of chickpea ( Cicer arietinum L .) germplasm. Molecular Genetics and Genomics, v. 261, p. 354-363, 1999.

WANG, H.; WEI, Y.; YAN, Z.; ZHENG, Y. EST-SSR DNA polymorphism in durum wheat ( Triticum durum L .) collections. Journal of Applied Genetics, v. 48, n. 1, p. 35-42, 2007. 
YILDIRIM, A.; SÖNMEZOĞLU, Ö. A.; GÖKMEN, S.; KANDEMIR, N.; AYDIN, N. Determination of genetic diversity among Turkish durum wheat landraces by microsatellites. African Journal of Biotechnology, v. 10, n. 19, p. 3915-3920, 2011.

YOUSFI, Y. Polymorphism of SSR markers located on chromosome 7A, in several wheat cultivars grown in Algeria. Romanian Agricultural Research, v. 26, n. 26, p. 25-28, 2009. 